\title{
Travellers as sentinels of chikungunya epidemics: a family cluster among Finnish travellers to Koh Lanta, Thailand, January 2019
}

Anu Kantele ${ }^{1}$

1. Inflammation Center, Department of Infectious Diseases, Helsinki University Hospital and University of Helsinki, Helsinki, Finland

Correspondence: Anu Kantele (anu.kantele@hus.fi)

Citation style for this article:

Kantele Anu. Travellers as sentinels of chikungunya epidemics: a family cluster among Finnish travellers to Koh Lanta, Thailand, January 2019 . Euro Surveill. 2019;24(11):pii=1900162. https://doi.org/10.2807/1560-7917.ES.2019.24.11.1900162

In January 2019, five of 11 travellers to Koh Lanta, Thailand, contracted chikungunya, symptoms starting 4 days after presumed transmission. Four cases were hospitalised, one child treated in intensive care; 6 weeks after disease onset, all three adults have persistent arthralgias/arthritis, incapacitating for two. Together with a recent report of eight chikungunya cases among travellers to various destinations in Thailand, the high attack rate in our cluster points to an ongoing outbreak in the country.

Recently, eight chikungunya cases were reported from various European countries and Israel, all returning from Thailand between November 2018 and February 2019 [1]. Here, we report a cluster of five chikungunya cases among 11 family members visiting Koh Lanta, an island district in Krabi Province, in the south of Thailand, in January 2019. Three of the eight cases in the earlier report had visited the same destination as this family [1].

\section{Case description}

A vacation was taken by a group comprising 11 relatives in four family units: family one (adult family members 1-2), family two (adult family members $3-4$ and children family members 5-6), family three (family members 7-8); family four (family members 9-11), resided at the same hotel in a popular tourist destination Koh Lanta, Thailand from mid-January 2019, having meals together. The ages of the family members ranged from 9 to 70 years, nine were adults, five were male. Their holiday trips were planned to last 1 or 2 weeks; family 4 returned to Finland after 1 week as scheduled.

On day 9 of their stay, family 2 (members $3-6$ ) spent the evening on the beach practicing sports, while families 1 and 3 only visited the beach briefly. The following day, members of the local population mentioned that there had been an unusually high number of mosquitoes, a 'mosquito invasion', the evening before. Family members 3-6 had applied mosquito repellents that morning and reported only a few bites, while family member 1 had not used any repellent and reported 60-70 mosquito bites all over his legs. Family members 3-6 and family member 1 all fell ill 4-6 days later (days 23-25 of stay in Thailand) with a systemic febrile disease and arthralgias. A description of the cases (in the order of symptom onset) can be seen in Table 1.

Family 2 was scheduled to return home after a stay of 14 days, but due to the severity of disease in the children (family members 5 and 6), the flight was postponed by 1 week. On return to Finland, the children were further hospitalised. On 1 March (38 days after presumed transmission), the children are back at school with minor arthralgias remaining. Family member 1 continues to have severe polyarthralgia and arthritis, but cannot use nonsteroidal anti-inflammatory drugs (NSAIDs) due to other medications, and has therefore been referred to a rheumatologist. Family member 3 has asthma as underlying disease; while her condition improved with a low dose etoricoxib (30 $\mathrm{mg}$ OD), higher doses resulted in an allergic reaction. Referral to a rheumatologist is planned if further clinical improvement under ibuprofen therapy (600 mg TD) is not observed. Family member 4 has arthralgia, but he manages on ibuprofen medication.

\section{Discussion}

Febrile systemic diseases in Thailand are not as common as other travel-related health problems like diarrhoea $[2,3]$, but often are more severe. Febrile systemic diseases include a large variety of mosquito-borne infections such as malaria, lymphatic filariasis and viral infections caused by Japanese encephalitis, zika, dengue and chikungunya viruses [4,5]. Prevention of these diseases relies heavily on mosquito avoidance, as vaccines are currently only available for 
Cluster of five laboratory-confirmed chikungunya cases in family cluster in order of symptom onset, Koh Lanta, January 2019

\begin{tabular}{|c|c|c|c|c|c|c|}
\hline $\begin{array}{l}\text { Sex/age group } \\
\text { (years) }\end{array}$ & $\begin{array}{l}\text { Underlying } \\
\text { diseases }\end{array}$ & $\begin{array}{l}\text { Clinical } \\
\text { symptoms }\end{array}$ & Outcome & $\begin{array}{l}\text { Information } \\
\text { available from } \\
\text { hospital in } \\
\text { Thailand }\end{array}$ & $\begin{array}{c}\text { CHIKV } \\
\text { diagnostic in } \\
\text { Finland (day } \\
\text { after symptom } \\
\text { onset) }\end{array}$ & $\begin{array}{l}\text { Other laboratory tests in Finland } \\
\text { (day after symptom onset) }\end{array}$ \\
\hline $\begin{array}{l}\text { Male/5-9 (family } \\
\text { member 5) }\end{array}$ & $\begin{array}{c}\text { Diabetes } \\
\text { mellitus type I }\end{array}$ & $\begin{array}{l}\text { Fever, rash, } \\
\text { arthralgia in } \\
\text { wrists, elbows } \\
\text { and back, } \\
\text { diarrhoea }\end{array}$ & $\begin{array}{l}\text { Return had to be delayed by } \\
\text { one week; } \\
\text { hospitalised in Thailand } \\
\text { and in Finland; persistent } \\
\text { arthralgia for } 20 \text { days } \\
\text { Evaluation on 1 March (day } \\
\text { 35): } \\
\text { Recovered fairly quickly } \\
\text { after return to Finland, only } \\
\text { minor arthralgias left }\end{array}$ & $\begin{array}{l}\text { RDT for dengue } \\
\text { positive, } \\
\text { CHIKV } \\
\text { antibodies } \\
\text { positive; final } \\
\text { diagnosis } \\
\text { coinfection } \\
\text { of dengue } \\
\text { fever and } \\
\text { chikungunya }\end{array}$ & $\begin{array}{c}\text { Anti-CHIKV } \\
\text { - IgM-positive; } \\
\text { - IgG >2,560 } \\
\text { by ELISA (day } \\
11 \text { ) }\end{array}$ & $\begin{array}{c}\text { Hb 103; leuc 8.2; tromb 541; eos } \\
\text { 0.17; CRP 51; LD 266; } \\
\text { blood culture negative; PCR } \\
\text { for bacterial stool pathogens: } \\
\text { enteroaggregative E. coli; stool } \\
\text { PCR for protozoa negative; } \\
\text { malaria tick and thin blood } \\
\text { smears negative; influenza A and } \\
\text { B by RDT negative; NS1 antigen } \\
\text { and dengue virus antibodies } \\
\text { negative } \\
\text { (day 11) }\end{array}$ \\
\hline $\begin{array}{l}\text { Female/10-14 (family } \\
\text { member 6) }\end{array}$ & Pollen allergy & $\begin{array}{l}\text { Fever, poor } \\
\text { condition, } \\
\text { suspicion of } \\
\text { septic shock, } \\
\text { low blood } \\
\text { pressure, rash, } \\
\text { arthralgia in } \\
\text { knees, heels } \\
\text { and toes }\end{array}$ & $\begin{array}{c}\text { Return had to be delayed } \\
\text { by one week; intensive care } \\
\text { in Thailand, treatment with } \\
\text { intravenous ceftriaxone; } \\
\text { hospitalised in Finland; } \\
\text { persistent arthralgia for } 28 \\
\text { days } \\
\text { Evaluation on } 1 \text { March (day } \\
\text { 35): } \\
\text { Clinical picture initially more } \\
\text { severe than for the others. } \\
\text { Recovered fairly quickly } \\
\text { after return to Finland, only } \\
\text { minor arthralgias left. }\end{array}$ & $\begin{array}{l}\text { RDT for dengue } \\
\text { weak positive } \\
\\
\text { (day } 2 \text { of } \\
\text { symptom } \\
\text { onset), CHIKV } \\
\text { antibodies } \\
\text { positive; final } \\
\text { diagnosis } \\
\text { dengue } \\
\text { fever and } \\
\text { chikungunya }\end{array}$ & $\begin{array}{c}\text { Anti-CHIKV } \\
\text { - IgM-positive } \\
\text { - IgG > 2,560 } \\
\text { by ELISA } \\
\text { (day 11) }\end{array}$ & $\begin{array}{c}\text { Hb 133; leuc 4.2; tromb 463; eos } \\
\text { o.08; CRP < 3; ALAT 43; LD 326; } \\
\text { blood culture negative; PCR } \\
\text { for bacterial stool pathogens: } \\
\text { negative; stool PCR for } \\
\text { protozoa: negative; NS1 } \\
\text { antigen and dengue virus } \\
\text { antibodies negative; MDR } \\
\text { colonisation negative for } \\
\text { MRSA, ESBL-PE, CPE, VRE, } \\
\text { multiresistant Acinetobacter, } \\
\text { multiresistant Pseudomonas } \\
\text { (day 11) }\end{array}$ \\
\hline $\begin{array}{l}\text { Male/70-74 (family } \\
\text { member 1) }\end{array}$ & $\begin{array}{c}\text { Diabetes } \\
\text { mellitus II, } \\
\text { hypertension, } \\
\text { cardiovascular } \\
\text { disease }\end{array}$ & $\begin{array}{c}\text { Fever, } \\
\text { arthralgia, } \\
\text { polyarthritis, } \\
\text { tenosynovitis, } \\
\text { itching of skin } \\
\text { (no rash) }\end{array}$ & $\begin{array}{l}\text { Evaluation on } 1 \text { March (day } \\
\text { 35): } \\
\text { Due to rivaroxaban } \\
\text { medication, non-steroidal } \\
\text { anti-inflammatory agents } \\
\text { contraindicated. Received a } \\
\text { one-week course of steroids } \\
\text { Disabling arthralgias and } \\
\text { arthritis continue; } \\
\text { Visited today a } \\
\text { rheumatologist and was } \\
\text { given intra-articular steroids } \\
\text { due to polyarthritis, } \\
\text { treatment ongoing. }\end{array}$ & Unknown & $\begin{array}{l}\text { Anti-CHIKV } \\
\text { - IgM positive } \\
\text { - IgG > 1,280 } \\
\text { by ELISA } \\
\text { (day 25) }\end{array}$ & $\begin{array}{l}\text { Hb 148; leuc 8.2; tromb 272; } \\
\text { eos 0.08; CRP } 3 \text {; ALAT 73; stool } \\
\text { culture for Salmonella, Shigella, } \\
\text { Campylobacter, Yersinia: } \\
\text { negative; NS1 antigen and } \\
\text { dengue virus antibodies negative } \\
\text { (day 25) }\end{array}$ \\
\hline
\end{tabular}

ALAT: alanine aminotransferase; CRP: C-reactive protein; CHIKV: chikungunya virus; SPE: carbapenemase-producing Enterobacteriaceae; CRP: C-reactive protein; EIA: enzyme-immuno assay; eos: eosinophils; ESBL-PE: extended-spetrum beta-lactamase-producing Enterobacteriaceae; Hb: haemoglobin; LD: lactate dehydrogenase; Leuc: leucocyte; MRSA: methicillin resistant Staphylococcus aureus; NS1: non-structural protein 1; PCR: polymerase chain reaction; RDT: rapid diagnostic test; tromb: trombocytes; VRE: vancomycin-resistant Enterococcus faecalis. Normal values: CRP (<3 mg/l); eos (0.03-0-44 E9/l); Hb (117-156 g/l); LD (115-235 U/l); leuc (3.4-8.2 E9/l); tromb (150-36o E9/l). 
Cluster of five laboratory-confirmed chikungunya cases in family cluster in order of symptom onset, Koh Lanta, January 2019

\begin{tabular}{|c|c|c|c|c|c|c|}
\hline $\begin{array}{l}\text { Sex/age group } \\
\text { (years) }\end{array}$ & $\begin{array}{l}\text { Underlying } \\
\text { diseases }\end{array}$ & $\begin{array}{l}\text { Clinical } \\
\text { symptoms }\end{array}$ & Outcome & $\begin{array}{l}\text { Information } \\
\text { available from } \\
\text { hospital in } \\
\text { Thailand }\end{array}$ & $\begin{array}{c}\text { CHIKV } \\
\text { diagnostic in } \\
\text { Finland (day } \\
\text { after symptom } \\
\text { onset) }\end{array}$ & $\begin{array}{l}\text { Other laboratory tests in Finland } \\
\text { (day after symptom onset) }\end{array}$ \\
\hline $\begin{array}{l}\text { Female/45-49 } \\
\text { (family member 3) }\end{array}$ & $\begin{array}{l}\text { Asthma } \\
\text { bronchiale }\end{array}$ & $\begin{array}{c}\text { Fever, } \\
\text { arthralgia/ } \\
\text { pain in ankles, } \\
\text { heels, achilles } \\
\text { tendons, } \\
\text { fingers, wrists; } \\
\text { diarrhoea; rash }\end{array}$ & $\begin{array}{l}\text { Return home had to be } \\
\text { delayed by one week, } \\
\text { persistent disabling } \\
\text { arthralgia, walking } \\
\text { difficulties. } \\
\text { Evaluation on 1 March (day } \\
\text { 34): } \\
\text { Started on day } 13 \text { after } \\
\text { symptom onset with } \\
\text { etoricoxib low dose ( } 30 \\
\text { mg), gradually increasing } \\
\text { to } 90 \text { mg, then rash; now } \\
\text { receiving ibuprofen, walking } \\
\text { difficulties, will be referred } \\
\text { to a rheumatologist unless } \\
\text { starts to improve soon. }\end{array}$ & $\begin{array}{l}\text { no visits to } \\
\text { healthcare }\end{array}$ & $\begin{array}{l}\text { Anti-CHIKV } \\
\text { - IgM positive } \\
\text { - IgG > 2,560 } \\
\text { by ELISA } \\
\text { (day 10) }\end{array}$ & $\begin{array}{c}\text { Hb 148; leuc 4.6, part of } \\
\text { lymphocytes reactive, a few } \\
\text { plasma cells; tromb 286; eos } \\
\text { o.05; CRP 51; ALAT 39; ASAT 18; } \\
\text { blood culture negative; stool PCR } \\
\text { for bacteria: enteropathogenic E. } \\
\text { coli; NS1 antigen negative; } \\
\text { very low levels of dengue virus } \\
\text { antibodies } \\
\text { (day 10) }\end{array}$ \\
\hline $\begin{array}{l}\text { Male/45-49 } \\
\text { (family member 4) }\end{array}$ & None & $\begin{array}{c}\text { Fever; } \\
\text { arthralgia, } \\
\text { strong pain in } \\
\text { heels, causing } \\
\text { inability to walk, } \\
\text { pain also in left } \\
\text { knee, wrists, } \\
\text { ankles; itching } \\
\text { of skin (no rash) }\end{array}$ & $\begin{array}{l}\text { Hospitalised in Thailand } \\
\text { until day } 4 \text { after onset of } \\
\text { symptoms; } \\
\text { Return had to be delayed } \\
\text { by one week; persistent } \\
\text { arthralgia. } \\
\text { Evaluation on } 1 \text { March (day } \\
\text { 33): } \\
\text { Started on day } 20 \text { after } \\
\text { symptom onset ibuprofen; } \\
\text { arthralgias continue but } \\
\text { are improving and patient } \\
\text { manages with current } \\
\text { medication. }\end{array}$ & $\begin{array}{c}\text { Dengue } \\
\text { antigen and } \\
\text { antibody, } \\
\text { malaria thick } \\
\text { and thin } \\
\text { blood smears, } \\
\text { influenza } \\
\text { antigen all } \\
\text { negative, } \\
\text { CHIKV } \\
\text { antibodies } \\
\text { positive; final } \\
\text { diagnosis } \\
\text { chikungunya }\end{array}$ & $\begin{array}{c}\text { Anti-CHIKV } \\
\text { - IgM positive } \\
\text { - IgG > 2,560 } \\
\text { by ELISA } \\
\text { (day 26) }\end{array}$ & $\begin{array}{l}\text { Hb 157; leuc 8.6; tromb 415; eos } \\
\text { 0.14; CRP } 33 \text {; ALAT 26; } \\
\text { NS1 antigen and dengue virus } \\
\text { antibodies by EIA negative } \\
\text { (day 26) }\end{array}$ \\
\hline
\end{tabular}

ALAT: alanine aminotransferase; CRP: C-reactive protein; CHIKV: chikungunya virus; SPE: carbapenemase-producing Enterobacteriaceae; CRP: C-reactive protein; EIA: enzyme-immuno assay; eos: eosinophils; ESBL-PE: extended-spetrum beta-lactamase-producing Enterobacteriaceae; $\mathrm{Hb}$ : haemoglobin; LD: lactate dehydrogenase; Leuc: leucocyte; MRSA: methicillin resistant Staphylococcus aureus; NS1: non-structural protein 1; PCR: polymerase chain reaction; RDT: rapid diagnostic test; tromb: trombocytes; VRE: vancomycin-resistant Enterococcus faecalis. Normal values: CRP (<3 mg/l); eos (o.03-0-44 E9/l); Hb (117-156 g/l); LD (115-235 U/l); leuc (3.4-8.2 E9/l); tromb (150-36o E9/l).

Japanese encephalitis [5]. Chikungunya virus (CHIKV) is transmitted, like dengue and zika viruses, by Aedes aegypti and Aedes albopictus mosquitoes [4,5] and has an incubation period of 3-7 days, symptoms beginning with an abrupt onset of fever followed by a predominating symptom of severe, sometimes disabling, polyarthralgia [6]. Some patients also develop a rash [6].

High attack rates of chikungunya pose a risk for tourists in areas where there is local transmission. Travellers can act as sentinels of outbreaks in a region. The cluster we present here accords with the findings by Javelle et al. [1] concerning Geosentinel sites describing a peak in chikungunya cases among visitors to Thailand. Of particular interest in our cluster is the high attack rate - with five of 11 travellers contracting chikungunya, all among the eight who stayed for longer than 1 week.
If, on return to their home countries, travellers are still viraemic and Aedes vectors prevail in their home country, there could be a risk of disease spread. Ae. albopictus appears to be the main vector for most of the European Union and European Economic Area, with Madeira as an exception since it also has an established Ae. aegypti population [7]. Aedes mosquitoes are only found in certain parts of central and southern Europe and the transmission period depends on temperature, usually not beginning before late spring [8].

In our cluster, four of the five cases had to be hospitalised in Thailand and one of the children required treatment in an intensive care unit. Severe manifestations and even deaths are seen in outbreaks, mostly among the elderly or those with underlying diseases [6]. Indeed, in our cluster, the two children had the 
most severe clinical picture in the acute phase and recovered fairly rapidly, whereas the symptoms persist longer among the adults: now, 6 weeks after the presumed transmission, the two children are nearly asymptomatic, while the three adults still have arthalgias/arthritis, for two of them incapacitating.

In one adult case, an underlying disease prevents the use of NSAIDs for post-acute chikungunya. Antirheumatic medications such as methotrexate and hydroxychloroquine are recommended alternatives, if the NSAIDs cannot be used [9]; while corticosteroids should not be taken in the acute phase, they may be needed in the chronic stage. Despite treatment, however, severe joint problems may continue for months or even years [6].

While travellers may act as sentinels of outbreaks in a destination, the peak observed in chikungunya cases in Thailand [1] calls for enhanced prevention also among forthcoming travellers. There is no vaccine available against chikungunya, and mosquito avoidance remains the sole preventive approach. Indeed, it also protects against dengue and zika viruses transmitted by the same mosquito species; even co-infections have been described $[10,11]$. Many travellers use mosquito repellents especially at dusk and dawn, the time malariatransmitting Anopheles mosquitoes bite. However, since the Aedes mosquitoes mostly bite in the daytime $[4,8]$, to shield themselves against chikungunya, dengue and zika viruses, travellers should also be advised to apply repellents during the day.

Thailand is a popular tourist destination in the world: in 2017 there were over 35 million visitors, 6.5 million arriving from Europe [12]. Many travellers to Thailand do not seek pre-travel advice [13] and it is thus a challenge reach them. Travel agencies, insurance companies and other actors outside the medical community should be approached as additional channels to reach out to tourists and deliver relevant information.

\section{Acknowledgements}

The author thanks MD PhD Heli Siikamäki for constructive comments on the manuscript.

\section{Conflict of interest}

None declared.

\section{Authors' contributions}

Anu Kantele was responsible for writing the manuscript and approving the final version. cases imported to Europe and the Middle East, early 2019. Euro Surveill. 2019;24(10):1900146. https://doi.org/10.2807/15607917.ES.2019.24.10.1900146 PMID: 30862335

2. Siikamäki H, Kivelä P, Fotopoulos M, Ollgren J, Kantele A. Illness and injury of travellers abroad: Finnish nationwide data from 2010 to 2012, with incidences in various regions of the world. Euro Surveill. 2015;20(19):21128. https://doi. org/10.2807/1560-7917.ES2015.20.19.21128 PMID: 25990358

3. Siikamäki H, Kivelä P, Fotopoulos M, Kantele A. A closer look at travellers' infections abroad: Finnish nationwide data with incidences, 2010 to 2012. Travel Med Infect Dis. 2017;15:29-36. https://doi.org/10.1016/j.tmaid.2016.10.007 PMID: 27773779

4. Leta S, Beyene TJ, De Clercq EM, Amenu K, Kraemer MUG, Revie CW. Global risk mapping for major diseases transmitted by Aedes aegypti and Aedes albopictus. Int I Infect Dis. 2018;67:25-35. https://doi.org/10.1016/j.ijid.2017.11.026 PMID: 29196275

5. Ferguson NM. Challenges and opportunities in controlling mosquito-borne infections. Nature. 2018;559(7715):490-7. https://doi.org/10.1038/s41586-018-0318-5 PMID: 30046071

6. Staples JE, Breiman RF, Powers AM. Chikungunya fever: an epidemiological review of a re-emerging infectious disease. Clin Infect Dis. 2009;49(6):942-8. https://doi. org/10.1086/605496 PMID: 19663604

7. European Centre for Disease Prevention and Control (ECDC). Aedes aegypti - current known distribution: January 2019. Stockholm: ECDC; 2019. Available from: https://ecdc.europa.eu/en/publications-data/ aedes-aegypti-current-known-distribution-january-2019

8. Schaffner F, Mathis A. Dengue and dengue vectors in the WHO European region: past, present, and scenarios for the future. Lancet Infect Dis. 2014;14(12):1271-80. https://doi. org/10.1016/S1473-3099(14)70834-5 PMID: 25172160

9. Runowska M, Majewski D, Niklas K, Puszczewicz M. Chikungunya virus: a rheumatologist's perspective. Clin Exp Rheumatol. 2018;36(3):494-501. PMID: 29533749

10. Furuya-Kanamori L, Liang S, Milinovich G, Soares Magalhaes RJ, Clements AC, Hu W, et al. Co-distribution and co-infection of chikungunya and dengue viruses. BMC Infect Dis. 2016;16(1):84. https://doi.org/10.1186/s12879-016-1417-2 PMID: 26936191

11. Waggoner IJ, Gresh L, Vargas MJ, Ballesteros G, Tellez Y, Soda $\mathrm{KJ}$, et al. Viremia and Clinical Presentation in Nicaraguan Patients Infected With Zika Virus, Chikungunya Virus, and Dengue Virus. Clin Infect Dis. 2016;63(12):1584-90. https:// doi.org/10.1093/cid/ciw589 PMID: 27578819

12. United Nations World Tourism Organization (UNWTO). eLibrary. Thailand: Country-specific: Basic indicators (Compendium) 2013-2017 (12.2018). Madrid: UNWTO. [Accessed: 28 Feb 2019]. Available from: https://www.e-unwto.org/doi/pdf/10.5555/ unwtotfb0764010020132017201812

13. Thomson CA, Gibbs RA, Giele C, Firth MJ, Effler PV. Health Seeking Behaviours and Knowledge of Infectious Disease Risks in Western Australian Travellers to Southeast Asian Destinations: An Airport Survey. Trop Med Infect Dis. 2016;1(1):E3. https://doi.org/10.3390/tropicalmed1010003 PMID: 30270854

\section{License, supplementary material and copyright}

This is an open-access article distributed under the terms of the Creative Commons Attribution (CC BY 4.0) Licence. You may share and adapt the material, but must give appropriate credit to the source, provide a link to the licence and indicate if changes were made.

Any supplementary material referenced in the article can be found in the online version.

This article is copyright of the authors or their affiliated institutions, 2019.

\section{References}

1. Javelle E, Florescu S-A, Asgeirsson H, Jmor S, Eperon G, Leshem $E$, et al. Increased risk of chikungunya infection in travellers to Thailand during ongoing outbreak in tourist areas: 